\title{
PELOS CORREDORES E QUARTOS DO HOSPITAL 6
}

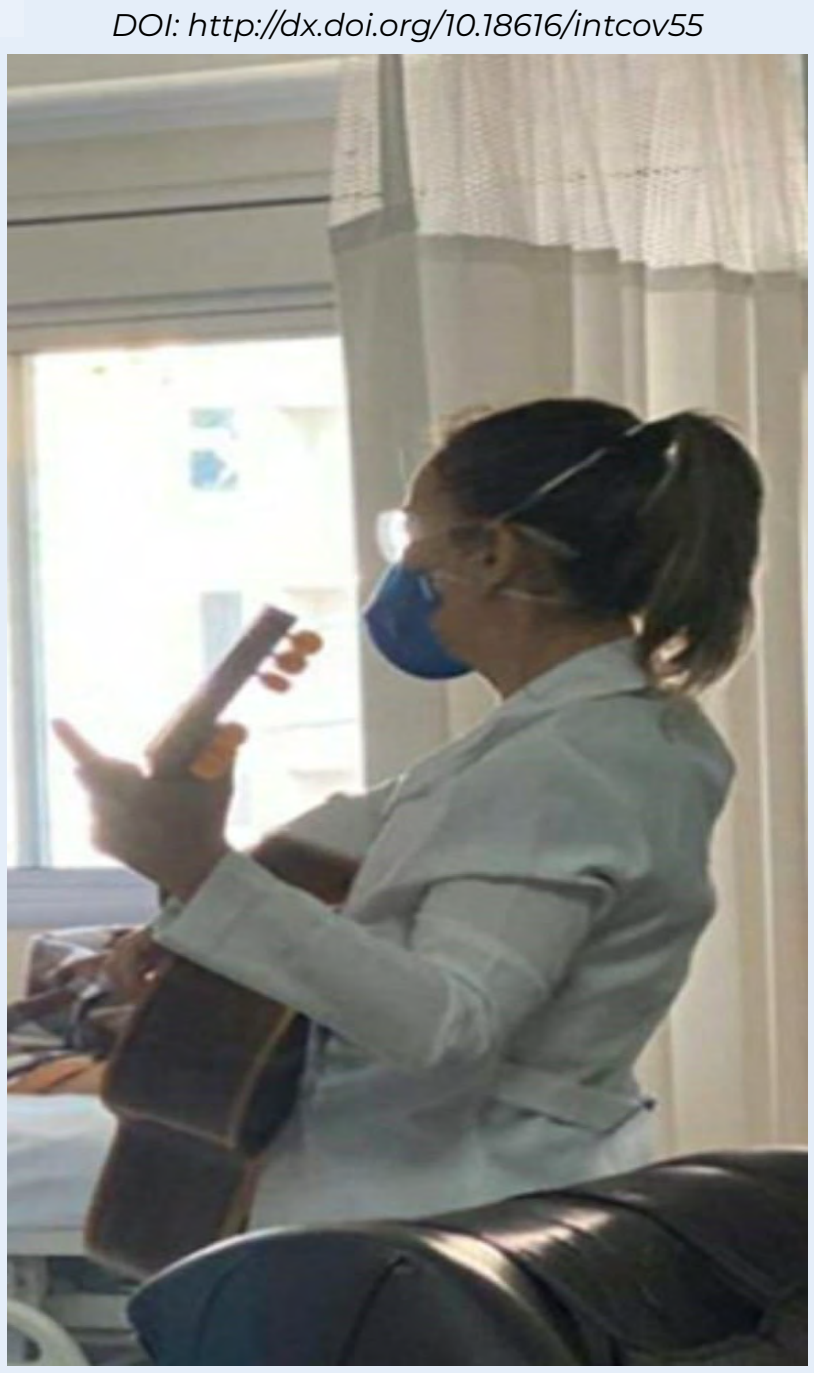

Créditos: Fernanda de Souza Fernandes.

6 O sentido da vida parece estar em viver o sagrado, presente em cada momento do viver. 